\title{
The on-Line Shopping Consumption Patterns of Saudi Shoppers
}

\author{
Faisal Fahhad Alsharif, François Siewe, Chris Fidler, and Giampaolo Bella
}

\begin{abstract}
The world is witnessing a significant change in the global economic dimension in recent years; this change is reflected in the transformation from traditional commerce to electronic commerce. Confirms this shifts the indicators and statistical estimates the growth of individuals online shoppers in the whole world. Through follow-up of these indicators is clear to the observer different shopping patterns from one country to another and from one society to another. The aim of this study is to identify the consumption patterns used in electronic shopping by the Saudis. To achieve this aim, the on-line questionnaire was used and the respondents were 472 participants. The results showed the lake of use and adoption on-line shopping although the high number of Internet users and increase the experience to use the computers and the Internet by Saudis. Also the results showed that the top five factors that encourage the Saudis to electronic shopping are as follows: Save time, cheaper, easy and faster shopping and delivery services.
\end{abstract}

Index Terms-E-commerce, on-line shopping.

\section{INTRODUCTION}

Recent statistics showed a growing number of Internet users to shop online around the world, especially in the developed world. This is because the difference between developed countries and other developing countries to technological development experienced by the Western industrial societies as one of the reasons leading to this marked difference.

More than 85 percent of the world's online population has used the Internet to make a purchase increasing the market for online shopping by 40 percent in the past two years. Among Internet users, the highest percentage shopping online is found in South Korea, where 99 percent of those with Internet access have used it to shop, followed by the UK (97\%), Germany (97\%), Japan (97\%) with the U.S. eighth, at 94 percent. Additionally, in South Korea, 79 percent of these Internet users have shopped in the past month, followed by the UK (76\%) and Switzerland (67\%) with the U.S. at 57 percent. Globally, the most popular and purchased items over the Internet are Books (41\% purchased in the past three months), Clothing/Accessories/Shoes (36\%), Videos / DVDs / Games (24\%), Airline Tickets (24\%) and Electronic Equipment (23\%)

On-line shopping is becoming increasingly popular. Online retail sales are estimated to grow from $\$ 172$ billion in

Manuscript received December 16, 2012; revised March 10, 2013

The authors are with the Software Technology Research Laboratory, Faculty of Technology, De Montfort University (e-mailP05105100@myemail.dmu.ac.uk,_fsiewe@myemail.dmu.ac.uk, cf@myemail.dmu.ac.uk, giamp@myemail.dmu.ac.uk).
2005 to $\$ 329$ billion in 2010 [1].

Research, Inc put out a new five-year forecast today predicting that e-commerce sales in the U.S. will keep growing at a 10 percent compound annual growth rate through 2014. It forecasts online retail sales in the U.S. will be nearly $\$ 250$ billion, up from $\$ 155$ billion in 2009. Last year, online retail sales were up 11 percent, compared to 2.5 percent for all retail sales [2]

In Western Europe, Forrester expects a slightly faster 11 percent growth rate for online retail sales, going from $\$ 93$ billion (68 billion Euros) in 2009 to $\$ 156$ billion (114.5 billion Euros) in 2014. Forrester's estimates exclude online sales of autos, travel, and prescription drugs [2].

Some other stats from the U.S. forecast:

- E-commerce sales will represent 8 percent of all retail sales in the U.S. by 2014, up from 6 percent in 2009

- In 2009, 154 million people in the U.S. bought something online, or 67 percent of the online population (4 percent more than in 2008)

- Three product categories (computers, apparel, and consumer electronics) represented more than 44 percent of online sales ( $\$ 67.6$ billion) in 2009 [2].

\section{ON-LinE SHOPPING IN SAUDI ARABIA}

The activity of electronic commerce in Saudi Arabia is witnessing remarkable real growth in the last five years in particular. Many of the indicators and statistical reports indicate that. A new major survey of the internet users in Saudi Arabia was concluded by the Arab Advisors Group in January 2011. The survey revealed that around 39\% of adult internet users in Saudi Arabia buy products and pay for services online. The Arab Advisors Group conservatively estimates the number of these users to be around 3.1 million which is around $12 \%$ of the total population in Saudi Arabia. These e-commerce users have spent an estimated $\$ 3$ bn on buying products and paying for services through e-commerce transactions in 2010.

\section{ReSEARCH Methodology}

A survey is usually used to identify the behaviour of groups of people, their attitudes and/or their opinions on a specific event or their background. Survey focuses on obtaining data from a large group of people (or events) in a standardised and systematic way [3]. Questionnaires are an efficient method used to collect data when the researcher knows exactly what to ask and how to measure the variables of interest in order to achieve relevance and accuracy [4], [5]. Therefore, an online self-administered questionnaire was 
deemed to be the most suitable and practical method for collecting quantitative data for this study. As quantitative research, Statistical analysis used in this study is a descriptive analysis and frequencies to find out the opinions of the Saudis and their attitudes on the use of on-line shopping.

\section{SAMPLE DESCRIPTION}

A total of 472 respondents were answer the questionnaire with $212(45 \%)$ being female and $260(55 \%)$ male. There was gender imbalance in those who participated in the study and this difference was statistically significant, p-value = 0.002 . The age distribution for the respondents were $52.1 \%$, $34.3 \%, 11.9 \%$, and $1.7 \%$ in the age groups less than or equal to 25 years, 26 - 35 years, $36-45$ years, and greater than 46 years respectively as shown in Fig. 1 .

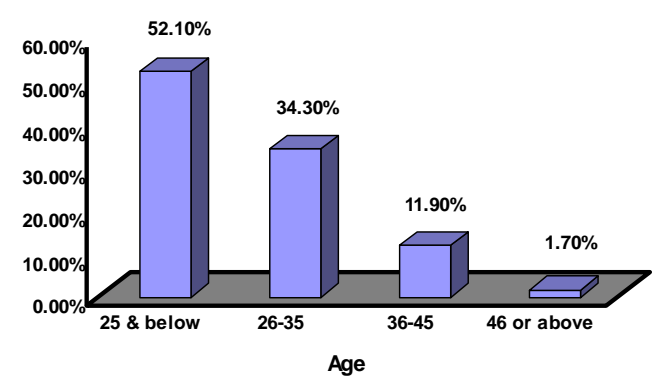

Fig. 1. Age distribution of participants.

Of the total, $13.1 \%$ of respondents were educated to high school level or below compared to $5.9 \%$ with Diplomas, $56.8 \%$ graduates (Bachelor's degree), and 20.8\% postgraduates (higher education) and $3.4 \%$ with other educational qualifications as shown in Fig. 2.

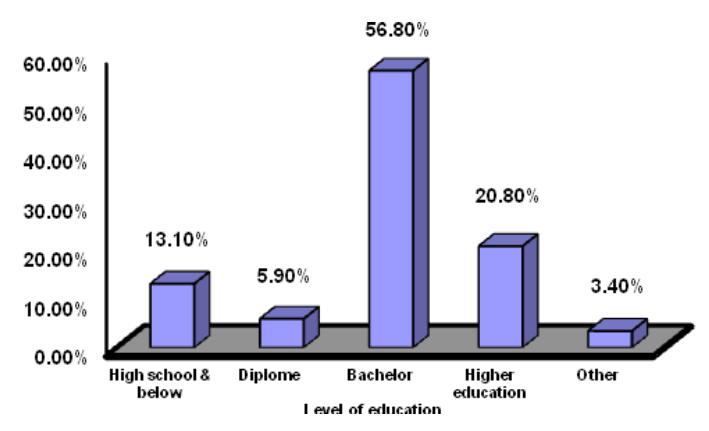

Fig. 2. Educational groups for participants

Of the total, 408 respondents were less than 35 years $(86.4 \%)$. Majority of the respondents were not in employment since they were students, $57.6 \%$ compared to $30.3 \%$ who were employed in the public sector, $10 \%$ in private sector and $2.1 \%$ are freelancers. $47.5 \%$ of the respondents were earning less than 3000 S.R, $12.3 \%$ between 3001 and 5999 S.R, 17\% between 6000 and 9000 S.R and $23.3 \%$ earning more than 9000 S.R.

\section{RESUlT AND CONCLUSION}

To achieve the objective of this study the respondents were asked to answer two questions, the first one was open question to explore the perspective of the participants about the on-line shopping.
Q1 In your opinion, what are the most important five factors that encourage you to shop on-line?

The results showed that the top five factors that encourage the Saudis to electronic shopping are as follows:

1) Save time

2) Cheaper

3) Easy

4) Faster shopping

5) Delivery

As expected, the results showed that the Saudis have sufficient awareness of the benefits of on-line shopping namely, saving time, cheaper price, ease of use and speed of shopping. The Saudis give e-delivery service (absent in S.A) much attention and acknowledge it as one of the benefits of on-line shopping. Compared to traditional shopping involving time and effort, online shopping from home or office saves time and is very convenient. Moreover, e-shoppers can have access to different websites and can discover many types of goods or products. They can compare quality and price regardless of the location of the seller without leaving home. The easiness and speediness of on-line shopping is one of the advantages of on-line shopping. The designers allocated lots of efforts to simplify the process of on-line shopping by design friendly interface. Nevertheless, increase of experience can overcome the difficult and complex task one faces by re- use on-line shopping. The house delivery service is one of the most important requirements for e-on-line shopping for the Saudis. This leads to an important fact, namely that the absence of this service may be one of the barriers to the adoption of on-line shopping in Saudi Arabia. The sixth importance factor according to the users is the lack of availability of some products in local markets, and this may be due to the existence of restrictions on these products. Electronic shopping to the Saudis is considered as an important opportunity to access the world markets to buy what they need. For women in Saudi Arabia, the inability of women to move and go out for shopping only with a relative (the principles of Islam) as well as the inherited habits is one of the motivators to use on-line shopping. An advantage of on-line shopping is to overcome these obstacles. Factors such as privacy trust and security comes in lower level of importance from the users' viewpoint. They are considered as barriers to use on-line shopping and are not encouraging factors.

The second question is about the frequencies use of on-line shopping activities.

\section{Q2 How frequently do you use e-commerce for the following services?}

All the activities in the Table I are listed under the umbrella of e-commerce, including buying through the Internet which is the subject of this study. The purpose is to avoid any ambiguity in the question, to allow the respondent to choose the right activity without any doubt or hesitation, and to know what type of activities are practiced by the Saudis when browsing the Internet. In addition the question is meant to highlight the depth of the problem of people's reluctance to use online shopping. 
The results in the table below showed that paying utility bills was the most commonly activity used on the internet, where $50 \%$ use it constantly, $18 \%$ occasionally $(M=3.93)$. Banking services activity was ranked second, with $41 \%$ of constant users and $20 \%$ occasional users $(M=2.73)$. Exchange of information was ranked third, with $36 \%$ using it constantly, and $17 \%$ using it occasionally $(M=2.55)$.

In contrast, activities such as buying, selling, and auction had the lowest users' frequency, where $77 \%$ do not sell via the Internet $(M=1.35)$ and $74 \%$ do not use auction $(M=$ 1.45). $49 \%$ of internet users in Saudi Arabia never buy online and $17 \%$ rarely buy online. Only $12 \%$ are buying constantly with very low average of 1.97 . These figures give a clear picture of the extent of the problem under the current study. These findings are consistent with studies that emphasize the low turnout of electronic shopping by Internet users in Saudi Arabia.

This fact is supported by the answer to the question, how long you have been using on-line shopping: $44 \%$ replied they do not use it at all, $11 \%$ replied less than one year. When asked on weekly basis, how many times do you use on-line shopping, $57 \%$ said they do not use it at all, $31 \%$ said they use it once a week. Fig. 3 illustrates the frequency distribution of the various activities of electronic commerce.

TABLE I: ACTIVITIES OF E-COMMERCE

\begin{tabular}{|c|c|c|c|c|}
\hline $\begin{array}{l}\text { E-C } \\
\text { Activities }\end{array}$ & Never & Rarely & Occasionally & Constantly \\
\hline $\begin{array}{l}\text { Buy } \\
\text { E.products/ } \\
\text { goods/tickets, } \\
\text { etc. }\end{array}$ & $\begin{array}{c}48.73 \% \\
(230)\end{array}$ & $\begin{array}{c}17.8 \% \\
(84)\end{array}$ & $\begin{array}{c}21.19 \% \\
(100)\end{array}$ & $\begin{array}{c}12.29 \% \\
(58)\end{array}$ \\
\hline $\begin{array}{l}\text { Sell: } \\
\text { E.products/ } \\
\text { goods/tickets, } \\
\text { etc. }\end{array}$ & $\begin{array}{c}77.54 \% \\
(366)\end{array}$ & $\begin{array}{l}12.5 \% \\
(59)\end{array}$ & $\begin{array}{c}6.78 \% \\
(32)\end{array}$ & $\begin{array}{l}3.18 \% \\
(15)\end{array}$ \\
\hline Bank services & $\begin{array}{c}29.24 \% \\
(138)\end{array}$ & $\begin{array}{c}9.75 \% \\
(46)\end{array}$ & $\begin{array}{c}19.7 \% \\
(93)\end{array}$ & $\begin{array}{c}41.31 \% \\
(195)\end{array}$ \\
\hline $\begin{array}{l}\text { Stock Market } \\
\text { Trade }\end{array}$ & $\begin{array}{c}58.26 \% \\
(275)\end{array}$ & $\begin{array}{c}11.23 \% \\
(53)\end{array}$ & $\begin{array}{c}15.68 \% \\
(74)\end{array}$ & $\begin{array}{c}14.83 \% \\
(70)\end{array}$ \\
\hline $\begin{array}{l}\text { Travelling } \\
\text { and Insurance } \\
\text { Services }\end{array}$ & $\begin{array}{c}39.83 \% \\
(188)\end{array}$ & $\begin{array}{c}16.53 \% \\
(78)\end{array}$ & $\begin{array}{c}20.13 \% \\
(95)\end{array}$ & $\begin{array}{c}23.52 \% \\
(111)\end{array}$ \\
\hline Paying Bills & $\begin{array}{c}24.58 \% \\
(116)\end{array}$ & $\begin{array}{l}7.2 \% \\
(34)\end{array}$ & $\begin{array}{c}18.22 \% \\
(86)\end{array}$ & $\begin{array}{c}50 \% \\
(236)\end{array}$ \\
\hline Auction & $\begin{array}{l}74.79 \% \\
(353)\end{array}$ & $\begin{array}{l}9.96 \% \\
(47)\end{array}$ & $\begin{array}{c}10.17 \% \\
(48)\end{array}$ & $\begin{array}{l}5.08 \% \\
(24)\end{array}$ \\
\hline $\begin{array}{l}\text { Information } \\
\text { Exchange }\end{array}$ & $\begin{array}{c}33.69 \% \\
(159)\end{array}$ & $\begin{array}{c}12.71 \% \\
(60)\end{array}$ & $\begin{array}{c}17.58 \% \\
(83)\end{array}$ & $\begin{array}{c}36.02 \% \\
(170)\end{array}$ \\
\hline
\end{tabular}

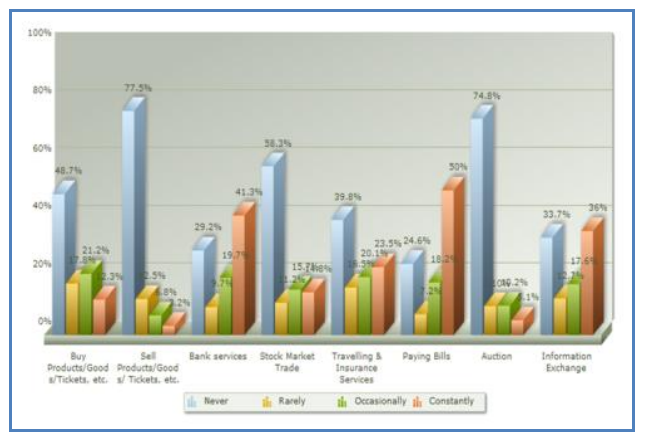

Fig. 3. Various activities of e-commerce

\section{REFERENCES}

[1]. C. A. Johnson, "Us Ecommerce: 2005 to 2010," in Forrester Research, 2005.

[2]. E. Schonfeld. Forrester Forecast: Online Retail Sales will grow to $\$ 250$ Billion by 2014. [Online]. Available: http://techcrunch.com/2010/03/08/forrester-forecast-online-retail-sale s-will-grow-to-250-billion-by-2014/

[3]. B. Oates, Researching information systems and computing, London SAGE, 2006.

[4]. U. Sekaran, Research Methods for Business: A Skill-Building Approach, Willey, Zikmund, 2000.

[5]. W. G. Zikmund, Business Research Methods, 5th ed. USA: The Dryden Press, 1997.

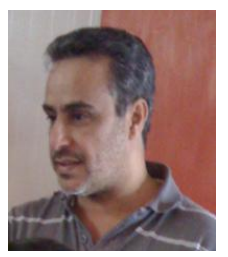

Faisal Fahhad Al-Sharif is a research student, Faculty of Technology, STRL, Software Technology Research Laboratory, De Montfort University, Bede Island Building, The Gateway, Leicester LE1 9BH, England.

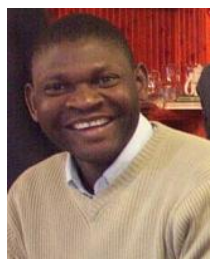

Francois Siewe is a senior research fellow, Research Themes: Theory and Computational Paradigms Requirement and Knowledge Engineering Computer Security and Trust. His research interests are Formal Methods, Ubiquitous Computing, Security, Policy Specification and Enforcement.

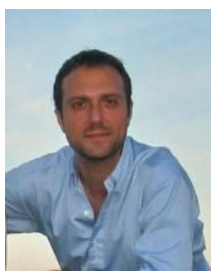

Giampaolo Bella is a research fellow, Research themes, Theory and Computational Paradigms, Computer Security and Trust. His research interests are Formal Specification and Verification of Critical Systems, Security Protocols

Chris Fidler is a principal lecturer, Faculty: Technology School/department: School of Computer Science and Informatics, Research group(s): Centre for Computing and Social Responsibility. Research interests, Business Intelligence (BI) Systems, Management Support Systems, Information Systems and their Effects on Organisations, People and Society, A sample of previous research subjects' domains of PhD students that he has successfully supervised are: Strategic Information Systems Planning and its application to Pakistan, Assessment of E-Government implementation within Jordan, Assessment of E-commerce security within Jordan. Ethics \& ICT research projects. 